\title{
Factors contributing to unfulfilment of and changes in fertility intentions in Czechia
}

\section{DOI: http://doi.org/10.26758/9.1.2}

\section{Hana HAŠKOVÁ (1), Kristýna POSPÍŠILOVÁ (1)}

(1) Department of Gender \& Sociology, Institute of Sociology of the Czech Academy of Sciences, Prague, Czech Republic

Address correspondence to: Hana Hašková and Kristýna Pospíšilová, Institute of Sociology of the Czech Academy of Sciences, Jilská 1, 11000 Prague 1, Czech Republic; Ph.: +420-210-310351; E-mail: hana.haskova@ soc.cas.cz; kristyna.pospisilova@soc.cas.cz

\begin{abstract}
Objectives. Achieved fertility is lower than intended fertility in Europe. The factors contributing to this mismatch are thus an important research topic. The objective of this study is to identify the factors that contribute to the unfulfilment of short-term fertility intentions and to changes in the intended number of children to improve our understanding of the mismatch between achieved and intended fertility in Czechia.

Material and methods. Binary logistic regression is applied to data on people aged 18-45 from two waves of the Generations and Gender Survey from 2005 and 2008 to explore what factors contribute to the unfulfilment of short-term fertility intentions, and to the Life Course 2010 data on people aged 25-60 from 2010 to identify what factors contribute to changes in the intended number of children. Descriptive statistics show the most cited reasons for the downward or upward changes in fertility intentions.

Results. The results show the importance of gender, partner, age, cohort, and the two-child norm for the chance that short-term fertility intentions will be left unfulfilled and the chance that people will change the number of children they plan to have. The results confirm that short-term fertility intentions are predictors of fertility behaviour, and labour market instability and siblings are factors that influence the number of children a person intends to have. Economic conditions, health, and the absence of a partner are the main reasons given to explain downward changes in the number of children people plan to have, while a change of values / new experiences and the influence of one's partner explain upward changes.

Conclusions. This study contributes to existing knowledge by testing factors associated with both, the fulfilment of short-term fertility intentions and changes in lifetime fertility intentions. They are rarely analysed together, although they both contribute to the postponement of childbearing and the mismatch between intended and achieved fertility.
\end{abstract}

Keywords: fertility intentions, changes in fertility intentions, low fertility, post-socialist context.

\section{Introduction}

Despite the decline in fertility in most European countries to a level below two children per woman, the ideal of having two children in a family still exists in most European countries (Sobotka and Beaujouan, 2014). The distinction between the ideal, personally preferred, intended and actual number of children that people have has led researchers to study the factors contributing to the differences.

Fertility ideals regarding the ideal number of children in the family have been repeatedly studied across European countries and are considered a good indicator of the 
prevailing norms in a society (ibid.). Studying the preferred/desired number of children people want to have in their life brings researchers closer to a person's personal situation than fertility ideals. Survey questions on personal preferences/desires often conclude with the qualification 'under ideal conditions' or 'regardless of your current situation' and emphasise in particular the person's value orientation, while other circumstances in a person's life remain rather overlooked (Kuhnt, Kreyenfeld and Trappe, 2017). Most often, therefore, research focuses on investigating fertility intentions. Panel data make it possible to examine even the extent to which fertility intentions are fulfilled, although usually only in the short term of several years (e.g. Št'astná, 2011; Szalma and Takács, 2015; Berrington, 2004; Testa and Toulemon, 2006).

Among the concepts mentioned above fertility intentions are considered the best indicator of potential behaviour because this concept focuses on the variety of circumstances that may affect fertility behaviour (Miettinen and Szalma, 2014). However, as panel data show, even fertility intentions often remain unfulfilled (e.g. Št’astná, 2011; Szalma and Takács, 2015; Berrington, 2004; Testa and Toulemon, 2006). And they remain unfulfilled more frequently in some populations than others - for example, among young people and people with lower education (Testa and Toulemon 2006; Smallwood and Jefferies, 2003; Berrington, 2004). Unlike fertility ideals, but also unlike personal preferences/desires, fertility intentions undergo more frequent changes throughout an individual's life. They do so in response to the changing circumstances of a person's life (Kuhn, Kreyenfeld and Trappe, 2017). While fertility ideals and personal preferences/desires are both significantly shaped by societal expectations, fertility intentions reflect as well as societal expectations also changes in an individual's personal circumstances to a greater extent than the other two concepts (Riskind and Patterson, 2010). If the central interest is to research the factors that shape individual ideas about whether, when, and how many children a man or a woman will have in their lives, fertility intentions are therefore the most appropriate concept of the three (ibid.). At the same time, it should be borne in mind that fertility intentions need not necessarily coincide with the actual fertility behaviour of a man or a woman in the future as intentions can change over time and are only one of the possible factors that influence the fertility outcomes of an individual. Unforeseen experiences (such as a breakup with a partner, disagreement over reproductive intentions in a partnership, or when the experience of raising a child proves to be different from what was expected) may lead an individual to change their fertility intentions (Iacovou and Tavares, 2011). In addition, even at a time when contraceptives are widely available, not all births are planned.

Although fertility ideals, personal preferences/desires, and intentions are operationalised in various ways in different studies, it is the consensus that the basic line towards fertility outcomes is the line that runs from fertility ideals, to personal preferences/desires and then to intentions (Sobotka and Beaujouan, 2014).

Previous studies have shown that fertility intentions decline with increasing age in the case of both women and men because people are likely to adjust the number of children they expect to have in response to biological constraints and prevailing age norms (Ní Bhrolcháin, Beaujouan and Berrington, 2010; Iacovou and Tavares, 2011). However, as Smallwood and Jefferies (2003) conclude, the fact that the intended number of children declines with increasing age should not necessarily be interpreted as signifying what they call the 'unmet need for fertility'. The difference between intentions and subsequent fertility is likely to be both a result of the fact that intentions tend to be uncertain in nature and they are often modified in response to subsequent life events and circumstances.

Consequently, in this study we focus on fertility intentions and explore not only what factors contribute to short-term fertility intentions being fulfilled or not in Czechia. Since fertility behaviour is considered to be the outcome of sequential decision-making (Iacovou and Tavares, 2011), we explore also factors that contribute to changes in individual fertility intentions in the region. Altogether, the study contributes to the understanding of unfulfilled short-term fertility 
intentions and changes in the total intended number of children that are behind the existing gap in the country between fertility intentions on the one hand and fertility outcomes on another hand.

There remains a strong orientation in Czechia towards the two-child family model (Rabušic and Chromková Manea, 2013). The low age of women at first birth and relatively high fertility around two children per woman were typical characteristics of reproduction during the last decades of the state-socialist era (Sobotka, 2004; Šprocha et al., 2016). Since the 1990s, the age of women at first birth has rapidly increased from 21 to 28 years. Meanwhile, total fertility rates declined from 1.9 children per women in 1990 to 1.2 in 1999, and they then increased to 1.6 when among people born in and after the late 1960s some of the 'postponed' births were realised at a later as they started to have children later than previous cohorts typically did. Since not all the 'postponed' births were ultimately realised at a later age, cohort fertility slightly declined among the cohorts that started to postpone childbearing in Czechia (Šprocha et al., 2018). Nevertheless, the two-child family is still the ideal family size in Czechia and this ideal is very stable (e.g. representative surveys on Czech population repeated by Public Opinion Research Centre of the Institute of Sociology of the Czech Academy of Sciences between 2004 and 2016 proved that constantly $69-71 \%$ of the population consider the two-child family to be their ideal family size; see Čadová, 2016).

In line with previous literature our study differentiates between short-term fertility intention, measured as one person's intention to have a child in the next three years, and a person's lifetime fertility intention in the sense of the total number of children they plan to have. While a short-term intention refers to the intended timing of when to have a (another) child in one's life (regardless the total number of children one intends to have in life), the lifetime fertility intention refers to the intended number of children (regardless of the timing of their birth).

Testing what factors contribute to the non-fulfilment of short-term fertility intentions and what factors contribute to changes in the lifetime fertility intentions is based on the results of previous studies. These studies suggest that partnership status is one of the main factors that distinguish people who fulfil and those who do not fulfil their short-term fertility intentions, and that changes in partnership status also contribute to changes in fertility intentions (e.g. Iacovou and Tavares, 2011; Hayford, 2009; Spéder and Kapitány, 2009; Št'astná, 2011). This is because people usually plan to have children when they are part of a couple and they need to negotiate their fertility intentions with their partner, whose fertility intentions may differ, and this can lead to adjustments to individual fertility intentions (Iacovou and Tavares, 2011).

As Bernardi (2003) points out, people's fertility intentions are influenced not just by their partner, as the effect of peer influence may also be significant. Moreover, some studies suggest that there may be differences between cohorts in terms of fulfilling and adjusting their fertility intentions as influential historical events (such as economic crisis or post-1989 socioeconomic transformation in Central and Eastern Europe) affect the lives of people of different cohorts in different phases of live. Philipov, Spéder and Billari (2005, p. 26) underlined that the quick drop in fertility in Central and Eastern Europe after 1989 was caused by social anomy when planning irreversible events with life-long effects (such as a childbirth) became difficult and led people in childbearing age to postpone these events. Sobotka, Skirbekk and Philipov (2011) showed that the economic crisis after 2008 intensified the postponement of childbearing by the means of increasing unemployment and insecurity. And others have shown that the effect of perceived labour market insecurity on fertility intentions is reduced or intensified by the age (Fahlén and Oláh, 2018).

While Fahlén and Oláh (2018) showed that perceived labour market instability has a negative effect on the intention of becoming a parent, Buhr and Kuhnt (2012) did not find employment status to have any significant effect on changes in fertility intentions, and Št'astná 
(2011) did not find employment status to have any significant effect on having a child as soon as intended.

And the same applies to education. While Št'astná (2011) did not find any effect of education on the fulfilment of short-term childbearing intentions in Czechia, Testa and Toulemon (2006) showed that in France, higher-educated people better predict their future fertility outcomes.

Last but not least, the two-child norm that is well documented across Europe could have a significant effect on fertility intentions, their fulfilment, and changes in fertility intentions because it is easier for a person to conform to societal expectations than it is for them not to do so (Iacovou and Tavares, 2011).

\section{Material and methods}

In this paper we explore: What factors contribute to the fulfilment or not of men's and women's short-term fertility intentions? What factors contribute to changes during one's adulthood to lifetime fertility intentions? What reasons do people give for changing their lifetime fertility intentions?

To identify what factors contribute to the fulfilment or not of the short-term fertility intentions of men and women of reproductive age in Czechia we analysed longitudinal panel data on the Czech population drawn from the international Generations and Gender Survey (GGS). In 2005 the first wave of this survey was conducted in Czechia and respondents were asked about their short-term (during next three years) and long-term intention to have a (another) child. The following questions were central to our analysis:

'Do you intend to have a (another) child during the next three years?' The possible answers were: definitely yes, probably yes, probably not, definitely not.

'Supposing you do not have a/another child during the next three years, do you intend to have any (more) children at all?' The possible answers were: definitely yes, probably yes, probably not, definitely not.

The second wave of the GGS survey was conducted in Czechia in 2008; therefore, it was possible to identify whether or not those people who in 2005 intended to have a (another) child did have a (another) child in the next three years. This data allowed us to answer our first research question on what factors contribute to the fulfilment or not of the short-term fertility intentions among men and women of reproductive age in Czechia. To answer this question we selected a population of men and women aged 18-45 in 2005 who intended in 2005 to have a (another) child ( $\mathrm{N}=538$ respondents).

To identify what factors contribute to the non-fulfilment of short-term fertility intentions, we applied a binary logistic regression to the GGS data (Model 1). The dependent variable is binary: s/he had (0) or did not have (1) a (another) child between 2005 and 2008. Beta coefficients (B) and exposed beta coefficients (Exp (B)) are presented in Model 1. All the explanatory variables in the Model 1 are categorical. One category is always the reference category (ref.) and the other categories of this variable are compared to the reference category. If the $\operatorname{Exp}(\mathrm{B})$ for some of the categories is higher than 1, the chance of not having a (another) child in the next three years is higher than for the reference category.

To explore what factors are associated with lifetime fertility intentions to change during adulthood and what reasons people give for having changed their lifetime fertility intentions, we analysed data from the Life Course 2010 representative survey of the Czech population aged 2560 years ( $\mathrm{N}=4010$ respondents). Like the GGS, the Life Course 2010 dataset includes basic socio-demographic information, detailed information about respondents' parental and partnership trajectories, detailed information about their fertility intentions, data on their current family, work and housing situation, and a number of attitudinal questions on parenting and care, 
work and family orientation, and the division of gender roles. The following questions were central to our analysis:

'When you think about the past, have your intentions regarding the total number of children you will have in your lifetime ever changed in the course of your adulthood?' The possible answers were: yes, no, don't know.

Among those people who changed their lifetime fertility intentions during adulthood we examined what direction this change or changes led - that is, whether the change(s) led towards more or fewer children than they had expected in total or whether people became uncertain whether they want to have a child at all or whether people became certain they want to have a child or stay childless. Then respondents replied to an open question: 'Can you please tell me what the main reason for this change was?' The respondents' answers were then coded.

To identify what factors lie behind changes in people's lifetime fertility intentions during adulthood, we applied a binary logistic regression to the Life Course 2010 survey data (Model 2). The dependent variable is binary: s/he did not change (0) or changed (1) their lifetime fertility intentions during adulthood. All the explanatory variables in Model 2 are categorical. Beta coefficients (B) and exposed beta coefficients (Exp (B)) are presented in Model 2. If the $\operatorname{Exp}(\mathrm{B})$ for some of the categories is higher than 1, the chance that a person changed their lifetime fertility intentions during their adulthood is higher than for the reference category.

Finally, descriptive statistics were used to show what reasons people give as leading them to change their lifetime fertility intentions in the specified direction.

\section{Results}

We will first present the results of our analysis of GGS data and then the results of our analysis of the Life Course 2010 survey data.

\section{Factors associated with (non-)fulfilment of short-term fertility intentions}

Table 1 shows that among respondents who in 2005 claimed they definitely intended to a have a (another) child within the next three years, only $43 \%$ had fulfilled this plan by 2008 , while for the remaining 57\% of these respondents their intention remained unfulfilled. Among the respondents who in 2005 said that they would 'probably' have a (another) child within the next three years, the share of those who did is even smaller. And among the people who in 2005 intended to have a (another) child but later than within the next three years, only $7 \%$ had had a child by 2008. Table 1 thus confirms that fertility intentions are predictors of subsequent fertility behaviour. The relationship between fertility intentions and behaviour is not as strong as one might expect. A relatively large share of respondents who definitely or probably intended to have a (another) child in the next three years did not fulfil this intention, even though both the total fertility rate and the economy were increasing in Czechia between 2005 and 2008, i.e. it was a period of stability and growth.

Table 1. Descriptive statistics: having a (another) child between 2005 and 2008 among respondents who intended in 2005 to have a (another) child, GGS data

\begin{tabular}{|l|l|l|}
\hline & $\begin{array}{l}\text { a child was born between } \\
2005 \text { and } 2008(\%)\end{array}$ & $\begin{array}{l}\text { no child was born between } \\
2005 \text { and 2008 }(\%)\end{array}$ \\
\hline intention in 2005: definitely yes in three years & 43 & 57 \\
\hline intention in 2005: probably yes in three years & 21 & 79 \\
\hline intention in 2005: yes but later & 7 & 93 \\
\hline
\end{tabular}

Note: $N=536$ respondents aged 18-45 who intended in 2005 to have a (another) child and participated in both GGS waves. Source: GGS data for the Czech Republic, 2005 and 2008. 
The finding that a relatively large share of people who intend to have a child within the next few years do not fulfil their fertility intentions in the short term even if it is a time of social and economic stability, not a depression, led us to our first research question on what factors are behind the fulfilment or not of the short-term intention to have a child among men and women in reproductive age in Czechia. To answer this research question a binary logistic regression was applied to GGS data. Table 2 presents the descriptive statistics for the variables used in the binary logistic regression that is presented in Model 1.

Table 2. Descriptive statistics for variables used in Model 1, GGS data

\begin{tabular}{|c|c|c|c|}
\hline Variables & Categories & Number & Percentage $(\%)$ \\
\hline \multirow{3}{*}{$\begin{array}{l}\text { Childbearing intentions } \\
\text { in } 2005\end{array}$} & definitely intended to have a child within 3 years & 114 & 22 \\
\hline & probably intended to have a child within 3 years & 179 & 34 \\
\hline & intended to have a child later & 228 & 44 \\
\hline \multirow[t]{2}{*}{ Gender } & Men & 300 & 58 \\
\hline & Women & 221 & 42 \\
\hline \multirow{3}{*}{$\begin{array}{l}\text { Partnership status in } \\
2005\end{array}$} & co-resident partner & 229 & 44 \\
\hline & non-resident partner & 121 & 23 \\
\hline & no partner & 171 & 33 \\
\hline \multirow{3}{*}{$\begin{array}{l}\text { Number of children in } \\
2005\end{array}$} & 0 & 353 & 68 \\
\hline & 1 & 119 & 23 \\
\hline & 2 or more & 49 & 9 \\
\hline \multirow[t]{4}{*}{ Age in 2005} & $18-24$ & 149 & 29 \\
\hline & $25-29$ & 200 & 38 \\
\hline & $30-34$ & 116 & 22 \\
\hline & $35-45$ & 56 & 11 \\
\hline \multirow{3}{*}{$\begin{array}{l}\text { Highest education level } \\
\text { in } 2005\end{array}$} & primary to lower secondary & 346 & 66 \\
\hline & upper secondary to post-secondary & 74 & 14 \\
\hline & tertiary & 101 & 19 \\
\hline Total & & 521 & 100 \\
\hline
\end{tabular}

Note: $N=521$ respondents aged 18-45 who intended in 2005 to have a (another) child and participated in both GGS waves. Source: GGS data for the Czech Republic, 2005 and 2008.

In Model 1, the dependent variable is having/not having a (another) child between 2005 and 2008 among those respondents who intended in 2005 to have a (another) child.

The model shows that those who declared in 2005 that they probably intended to have a child within three years, had a 1.8 times $(80 \%)$ higher chance of not having a child within the next three years compared to the reference category of those who in 2005 said they definitely intended to a have a child within the next three years. And those who intended to have a child later had a 5.5 times higher chance of not having a child within the next three years than the reference category while controlling for the other variables in the model.

Gender is also statistically significant. Men had a 2.4 times higher chance of not having a child within the next three years compared to women while controlling for the other variables in the model.

Partnership also proved to be important. Regardless of whether the partner was coresidential or non-residential (even marital status was not statistically significant) those who did not have a partner had almost a 5 times higher chance of not having a child within three years compared to those with a partner. This shows the importance of having a partner for the realisation of fertility intentions. 
How many children respondents already had in 2005 also proved to be important. There was no difference between childless people and people who had only one child, but those who already had at least two children (i.e. a widely shared ideal family size in Czechia) had a 4 times higher chance of not having a child within three years than childless people. It shows that the transition to a bigger family than the two-child family is either more difficult than the transition to the first or the second child, or it points to the declining urgency to have another child when a person has already met the widely shared ideal family size in the country.

We also tested for the effect of age. Respondents aged 18 to 24 had almost a 3 times higher chance of not having a child within three years than respondents aged 25 to 29. This relates to the fact that the youngest people still have a long time to fulfil their fertility intentions and thus may decide to postpone having a (another) child more easily than older respondents. Moreover, older persons may feel more social pressure they should no longer postpone their fertility intentions.

Based on the previous literature we also controlled for the highest education level obtained, but no statistical differences in having a child within three years were found regarding the education level among those who intended to have a (another) child when controlling for the other variables in the model.

Although previous studies pointed out the possible effect of the employment status on the decision about having (another) child, especially among men (e.g. Szalma and Takács, 2018; Miettinen and Szalma, 2014), this variable was not statistically significant when using Czech data. The variable was then removed from the final model due to multi-collinearity in the data (high correlation with age and education).

In sum, Model 1 is in line with previous findings by Št'astná (2011) and shows that a higher chance to not having a (another) child in the next three years had among those who intended to have a (another) child those who were less certain about having a (another) child during the next three years or those who intended to have a (another) child later than in three years, men compared to women, respondents without a partner, those who already reached the widely shared ideal family size of two children in Czechia and young people in their teens or early twentieths. The specific values of B coefficients are showed in Model 1.

Model 1. Binary logistic regression, not having a (another) child between 2005 and 2008 among those who intended in 2005 to have a (another) child, GGS data

\begin{tabular}{|c|c|c|c|}
\hline Variables & Categories & $\mathrm{B}$ & $\operatorname{Exp}(\mathrm{B})$ \\
\hline \multirow[t]{3}{*}{$\begin{array}{l}\text { Fertility intentions in } \\
2005\end{array}$} & $\begin{array}{l}\text { definitely intended to have a child within } 3 \text { years } \\
\text { (ref.) }\end{array}$ & & 1 \\
\hline & probably intended to have a child within 3 years & 0.768 & $2.155^{* *}$ \\
\hline & intended to have a child later & 1.541 & $4.669 * * *$ \\
\hline \multirow[t]{2}{*}{ Gender } & Women (ref.) & & 1 \\
\hline & Men & 0.965 & $2.625 * * *$ \\
\hline \multirow{3}{*}{$\begin{array}{l}\text { Partnership status in } \\
2005\end{array}$} & co-resident partner (ref.) & & 1 \\
\hline & non-resident partner & 0.606 & 1.832 \\
\hline & no partner & 1.644 & $5.175^{* * *}$ \\
\hline \multirow{3}{*}{$\begin{array}{l}\text { Number of children } \\
\text { in } 2005\end{array}$} & 0 (ref.) & & 1 \\
\hline & 1 & 0.324 & 1.382 \\
\hline & 2 and more & 1.808 & $6.099 * *$ \\
\hline \multirow[t]{4}{*}{ Age in 2005} & $25-29$ (ref.) & & 1 \\
\hline & $18-24$ & 1.041 & $2.832 * *$ \\
\hline & $30-34$ & 0.252 & 1.287 \\
\hline & $35-45$ & 0.297 & 1.345 \\
\hline
\end{tabular}




\begin{tabular}{|l|l|r|r|}
\hline Variables & Categories & B & $\operatorname{Exp}(\mathrm{B})$ \\
\hline \multirow{2}{*}{$\begin{array}{l}\text { Highest education } \\
\text { level in 2005 }\end{array}$} & tertiary (ref.) & & 1 \\
\cline { 2 - 4 } & primary to lower secondary & -0.880 & 0.415 \\
\cline { 2 - 4 } & upper secondary to post-secondary & -0.294 & 0.746 \\
\hline Constant & & -0.643 & 0.526 \\
\hline
\end{tabular}

Note: $N=521$ respondents aged 18-45 who intended in 2005 to have a (another) child and participated in both GGS waves. Omnibus Test of Model Coefficients $=0.000 . R^{2}=0.32$. Hosmer and Lemeshow Test $=0.724$.

Ref. $=$ reference category; $*=p<0.05 ; * *=p<0.01 ; * * *=p=000$.

Source: GGS data for the Czech Republic, 2005 and 2008.

\section{Factors associated with changes in lifetime fertility intentions}

The second research question in this paper is what factors lead people during the course of their adulthood to change their intended overall number of children? To answer this question binary logistic regression was applied to the data from the Life Course 2010 survey. Table 3 presents the descriptive statistics for the variables used in the binary logistic regression that is presented in Model 2.

Table 3. Descriptive statistics for variables used in Model 2, Life Course data 2010

\begin{tabular}{|c|c|c|c|}
\hline Variables & Categories & Number & Percentage $(\%)$ \\
\hline \multirow[t]{4}{*}{ Intended number of children } & 0 & 814 & 21 \\
\hline & 1 & 804 & 21 \\
\hline & 2 & 1782 & 46 \\
\hline & 3 or more & 428 & 11 \\
\hline \multirow[t]{2}{*}{ Gender } & Men & 1937 & 51 \\
\hline & Women & 1891 & 49 \\
\hline \multirow{4}{*}{$\begin{array}{l}\text { Partnership history (only living } \\
\text { with a partner for at least } 6 \\
\text { months was considered) }\end{array}$} & never lived with a partner & 783 & 20 \\
\hline & lived with 1 partner & 2365 & 62 \\
\hline & lived with 2 partners & 577 & 15 \\
\hline & lived with 3 or more partners & 103 & 3 \\
\hline \multirow{3}{*}{$\begin{array}{l}\text { Experience with } \\
\text { unemployment }\end{array}$} & no experience & 2941 & 77 \\
\hline & 1 experience with unemployment & 721 & 19 \\
\hline & 2 or more periods of unemployment & 166 & 4 \\
\hline \multirow[t]{2}{*}{ Number of siblings } & no siblings & 521 & 14 \\
\hline & 1 or more siblings & 3307 & 86 \\
\hline \multirow[t]{3}{*}{ Age (date of birth) } & 34 and younger (born 1976 and later) & 1208 & 31 \\
\hline & $\begin{array}{l}35 \text { to } 45 \text { (born between } 1965 \text { and } \\
1975 \text { ) }\end{array}$ & 1083 & 28 \\
\hline & 46 or older (born before 1965) & 1537 & 40 \\
\hline \multirow[t]{3}{*}{ Highest education level } & primary to lower secondary & 2059 & 54 \\
\hline & upper secondary to post-secondary & 1303 & 34 \\
\hline & tertiary & 466 & 12 \\
\hline Total & & 3828 & $100 \%$ \\
\hline
\end{tabular}

Note: $N=3828$ respondents aged 25-60. Source: Life Course 2010 survey.

From the total population analysed in the Life Course 2010 survey, a quarter of them declared that they had changed their total lifetime fertility intentions during the course of their adulthood. This share is in line with previous findings by Rabušic and Chromková Manea (2013). The data from the Life Course 2010 survey also include questions on what specific changes respondents had made to their intended overall number of children: a) a change in 
fertility intentions to a higher overall number of children than previously planned, b) a change in fertility intentions to a lower overall number of children than previously planned, c) a change where they became uncertain about whether to have a child at all, d) a change where they reached the decision to definitely have a child or e) a change where they reached the decision to remain childless. More than one-third of respondents who reported a change in the number of children they intended to have declared that they had made two (or even more) such changes during their adulthood. Most often people made downward revisions to their intended overall number of children (see Figures 1 and 2). A disadvantage of the Life Course 2010 survey dataset is that it is not possible to determine the order and the timing of different changes over the course of a person's adult years. We are therefore analysing what factors contribute to changes in the intended overall number of children in general, which may be considered an indicator of unstable parental intentions in adulthood.

In Model 2, the dependent variable is a change in the intended number of children in adulthood (s/he did not change (0), changed (1) her/his intentions).

The first variable in Model 2 is the intended number of children. This variable represents the real number of children for people who did not intend to have more or any children and the total intended number of children for people who did intend to have a (another) child(ren) in the future. The model shows that those who intended to remain childless or to have a single child had almost a 4 times higher chance of changing their intended number of children in their adulthood than the reference category made up of those respondents who intended to have 2 children in their life. Also those who intended to have 3 or more children had a 4 times higher chance of changing their intended number of children than the reference category. The results show that people whose fertility intentions equal the widely shared ideal of 2 children in Czechia are more stable in their intentions than others. The results may also suggest that people with a non-normative lifetime fertility intention (zero, one, three or more children) changed their intended overall number of children more often than those who intended to have 2 children in their life and they only arrived at the non-normative number of children they intended to have as a result of experiences and events that occurred in the course of their adult life.

Gender also proved to be statistically significant in Model 2. Women had a 1.8 times (80\%) higher chance of changing their intended overall number of children during adulthood than men.

Co-residential partnership history also proved to be statistically significant. The more partners the respondent lived with (only living together for at least 6 months was considered) during his or her life, the higher the chance was that he or she changed the intended number of children. This shows that people adapt their fertility intentions to their partners' intentions and life trajectories; it may also reflect a downward effect of partnership dissolution on fertility intentions followed by an upward effect of re-partnering for some of them though. While previous research has shown a downward effect of partnership dissolution on fertility on an individual level, the effect of re-partnering on fertility is less obvious and seems to depend on gender (Beaujouan and Solaz, 2013) and whether both partners have already children from previous partnerships or not (Murinkó and Szalma, 2016). Moreover, when only one of the partners have a pre-union child, family and gender role attitudes, family policies and demographic trends seem to influence the effect of re-partnering on fertility (ibid.).

The effect of experience with unemployment was also tested. Those respondents who had personally experienced unemployment once had a 1.3 times $(30 \%)$ higher chance of having changed their intended overall number of children in adulthood than the reference category made up of those respondents who had never experienced unemployment; those who had experienced unemployment two or more times had even a 1.6 times $(60 \%)$ higher chance of having changed their intentions compared to the reference category. If experience with unemployment is 
considered to be an indicator of labour market instability or insecurity, then a change or changes in the overall intended number of children may reflect labour market instability or insecurity.

Moreover, respondents with siblings had almost a 1.4 times $(40 \%)$ higher chance of having changed their intended number of children compared to respondents without any siblings. This may reflect the fact that not only do people adapt their fertility intentions to their partner's intentions and life trajectories, but that their fertility intentions are also influenced by their peers (Bernardi, 2003) and siblings are just a special kind of peer group with whom a person may compare or synchronise their life trajectories. The idea that siblings may increase the chance of changing one's intended number of children has been suggested by previous research. Szalma and Takács (2018) pointed to the situation when a person changes his/her fertility intention because his/her sibling has many children and thus the person does not need to reproduce. Moreover, Hašková (2009) pointed to an increased pressure to reproduce from parents on their childless adult children in their late twenties to early forties when there were no grandchildren (yet), and a decline of this pressure on the remaining childless adult children when the parents became grandparents due to one of their children's entry into parenthood. These studies suggest that siblings' children may have the effect of declining one's need to reproduce and that siblings' childlessness may have the effect of increasing one's feeling of obligation to give grandchildren to their parents. Since we expected that the effect of siblings might not be the same for men and women, interaction between gender and siblings was tested in the model but was not statistically significant. According to this result, the effect of siblings does not differentiate between men and women (or - more information is needed, e.g. not only information on the respondent's gender but also gender of his/her siblings).

The next variable in Model 2 divides respondents into three categories based on their year of birth (age). The oldest respondents, born before 1965, are the reference category here. People born between 1965 and 1975 represent the cohorts who introduced the 'new reproductive regime' into the country, because they were aged 15-25 at the beginning of the 1990s before total fertility rates dramatically dropped and the age of women at the first birth started its rapid increase. In the 'new reproductive regime', which has gained strength in Czechia since the 1990s, people typically have fewer children over the course of their reproductive years and have them later than they did in the 'old reproductive regime'. This new regime became a part of Czechia's demographic and social reality alongside the process of childbearing postponement. In contrast, the 'old reproductive regime' was typical for the cohorts that gave birth during the state-socialist era in Czechoslovakia (represented by the reference category), when total fertility rates were around 2 children per woman and mothers were almost always married before they gave birth to their first child at around the age of 20-22 (Sobotka, 2004, p. 320). The youngest respondents were born 1976 and later and it is highly probable that some of them will still make some changes in their fertility intentions in the future. Model 2 shows that people from the cohorts who were in their prime reproductive age at the time of the post-1989 social transformation in the 1990s and the first decade of the new millennium and who initiated the 'new reproductive regime' in the country had a 1.3 times (30\%) higher chance of changing their intended number of children in adulthood compared to the reference category. The youngest people born 1976 and later do not differ significantly from the reference group, which represents the 'old demographic regime'.

These results suggest that the post-1989 social transformation and the transition from early to later childbearing had a significant effect on the cohorts who started to postpone childbearing and experienced a significant drop and very low fertility rates in their prime reproductive age. The people who were in their prime reproductive age during the post-1989 social transformation and introduced the 'new reproductive regime' had more unstable fertility intentions, which is signalled by the fact that they more than other respondents declared their fertility intentions changed during their adult years. Since the youngest group of respondents 
were still relatively young when surveyed, it is also possible that a significant share of them will change their lifetime fertility intentions later when they are older, and their intentions may prove to be as unstable as those of the 1965-1975 cohorts. If this is the case, the above-mentioned interpretation needs to be changed. Such a situation would simply mean that the increasing length of time that young adults remain childless before establishing a family relates to an increased chance of a person changing the overall intended number of children over the life course.

The highest level of education attained by the respondents was included in Model 2 as a control variable, but it showed no statistically significant differences concerning changes in lifetime fertility intentions during adulthood by education.

In sum, Model 2 shows that the chance of the overall intended number of children changing during adulthood was greater among people with non-normative parental intentions, women, respondents with a more extensive co-residential partnership history, respondents who had experienced unemployment at least once (i.e. they had experienced labour market and economic instability or insecurity), those who had at least one sibling, and those who were from the cohorts who introduced the 'new demographic regime' in Czechia. The specific values of B and $\operatorname{Exp}(\mathrm{B})$ coefficients are listed in Model 2.

\section{Model 2. Binary logistic regression, changes in the intended overall number of children}

\begin{tabular}{|c|c|c|c|}
\hline Variables & Categories & $\mathrm{B}$ & $\operatorname{Exp}(\mathrm{B})$ \\
\hline \multirow[t]{4}{*}{ Intended number of children } & 2 (ref.) & & 1 \\
\hline & 0 & 1.282 & $3.604 * * *$ \\
\hline & 1 & 1.364 & $3.912 * * *$ \\
\hline & 3 or more & 1.407 & $4.086 * * *$ \\
\hline \multirow[t]{2}{*}{ Gender } & Men (ref.) & & 1 \\
\hline & Women & 0.566 & $1.762 * * *$ \\
\hline \multirow[t]{4}{*}{ Partnership history } & never lived with a partner (ref.) & & 1 \\
\hline & lived with 1 partner & 0.478 & $1.613 * * *$ \\
\hline & lived with 2 partners & 0.712 & $2.038 * * *$ \\
\hline & lived with 3 or more partners & 1.349 & $3.855 * * *$ \\
\hline \multirow[t]{3}{*}{ Experience with unemployment } & no experience (ref.) & & 1 \\
\hline & 1 experience with unemployment & 0.258 & $1.294 *$ \\
\hline & 2 or more periods of unemployment & 0.469 & $1.599 *$ \\
\hline \multirow[t]{2}{*}{ Number of siblings } & no siblings (ref.) & & 1 \\
\hline & 1 or more siblings & 0.316 & $1.371^{*}$ \\
\hline \multirow[t]{3}{*}{ Age (date of birth) } & 46 and older (born before 1965) (ref.) & & 1 \\
\hline & 34 and younger (born 1976 and later) & -0.103 & 0.902 \\
\hline & 35 to 45 (bort between 1965 and 1975) & 0.282 & $1.325^{* *}$ \\
\hline \multirow[t]{3}{*}{ Highest education level } & primary to lower secondary (ref.) & & 1 \\
\hline & upper secondary to post-secondary & 0.093 & 1.098 \\
\hline & tertiary & 0.165 & 1.179 \\
\hline Constant & & -3.434 & $0.032 * * *$ \\
\hline
\end{tabular}

Note: $N=3828$ respondents aged 25-60. Omnibus Test of Model Coefficients $=0.000 . R^{2}=0.13$. Hosmer and Lemeshow Test $=0.262$. Ref. $=$ reference category; $*=p<0.05 ; * *=p<0.01 ; * * *=p=000$.

Source: Life Course 2010 survey. 


\section{Reasons for changes in fertility intentions}

The data from the Life Course 2010 survey contain information on the specific direction in which a person's overall intended number of children changed (a change of fertility intentions to a higher overall number of children, a change to a lower overall number of children, a change to uncertainty, whether to have a child at all, a change to a decision to have a child or a change to remain childless). The small number of respondents who reported making only one specific change in their fertility intentions makes it impossible to analyse these sub-samples separately using binary logistic regression. Therefore descriptive statistics were used to illustrate at least the most frequently cited reasons for each of the specifically directed changes in fertility intentions that the respondents named as the main reason for the specific change in their intended overall number of children. It was an open question, i.e. no pre-defined replies were offered to the respondents. The respondents' replies were coded and then recoded into the following categories: economic situation (economic in/stability or housing situation); state of health; partner in the negative sense (the absence of a partner or unsuitable partner for having a(nother) child) and partner in the positive sense (having a partner who wants a child); feeling inappropriate for a (nother) child or that parenthood is too difficult; values, change of values, new experiences; unplanned parenthood; other.

When we focus on the reasons for downward changes - a change to having fewer children in their lifetime, a change to being uncertain about whether the respondent intends to have a child at all and a change to the decision to remain childless - the structure of the reasons is similar (Figure 1).

Figure 1 The most frequent reasons for downward changes in intended number of children

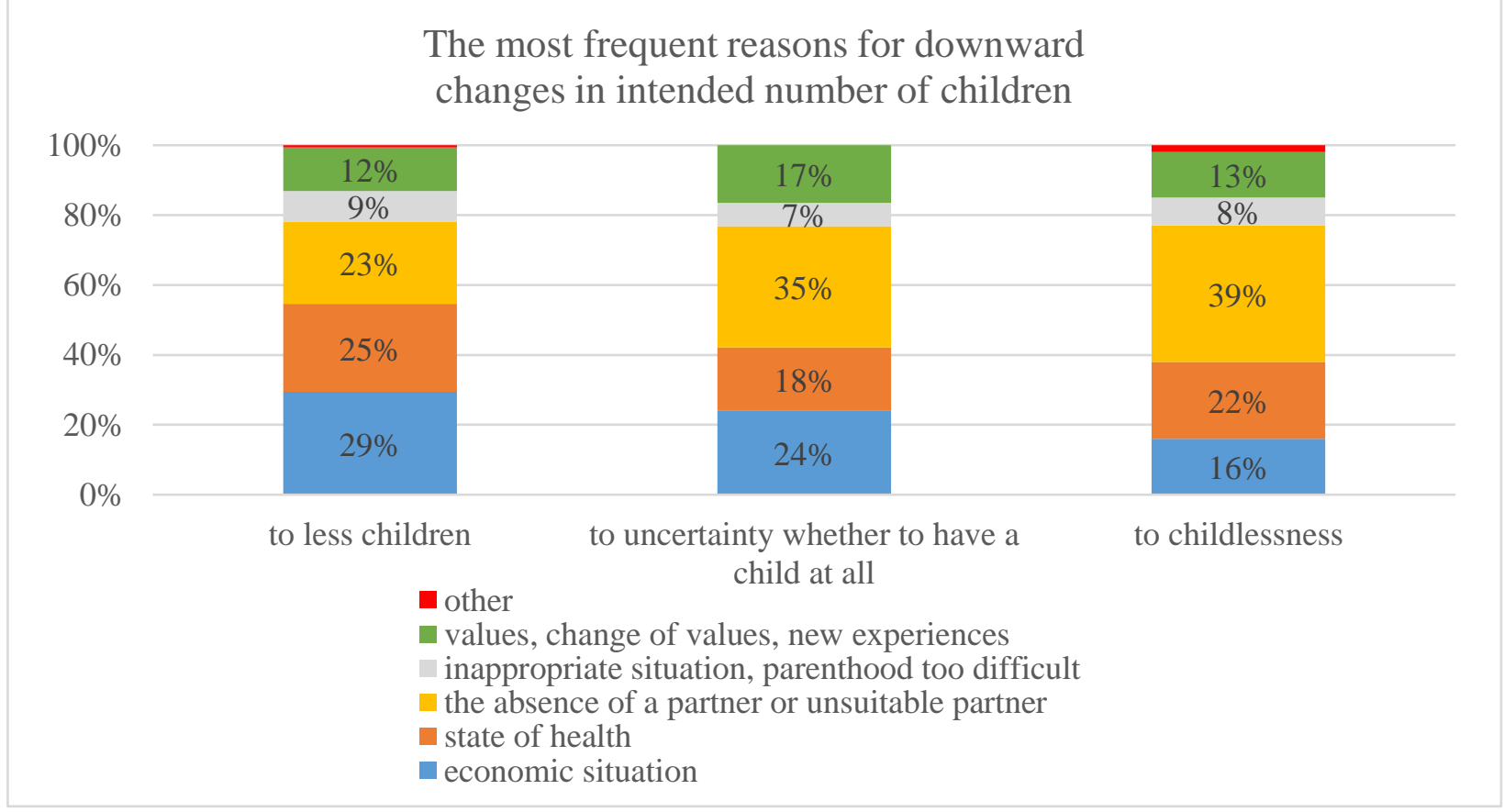

Note: Change to less children $(N=488)$; change to uncertainty whether to have a child at all $(N=134) ;$ change to childlessness $(N=107)$. Source: Life Course 2010 survey.

The first three reasons listed in differing order are: economic situation, state of health and the absence of a partner or having an unsuitable partner. The following reasons are cited for the change that leads to a lower intended overall number of children: economic situation is in first place with $29 \%$ of these respondents citing this reason, state of health ranks second at $25 \%$ and the absence of a partner or having an unsuitable partner is third at $23 \%$. When the change leads to uncertainty about whether or not to have a child at all, it is the absence of a partner or 
having an unsuitable partner that ranks first among the reasons cited at $35 \%$, economic situation is in second place at $24 \%$ and state of health is third at $18 \%$. When people's fertility intentions change to the decision to remain childless, the absence of a partner or having an unsuitable partner is the reason in first place at $39 \%$, state of health ranks in second place $(22 \%)$ and economic situation is third (16\%).

As expected, the structure of responses is different in the case of upward changes (Figure 2).

\section{Figure 2 The most frequent reasons for upward changes in intended number of children}

The most frequent reasons for upward changes in intended number of children

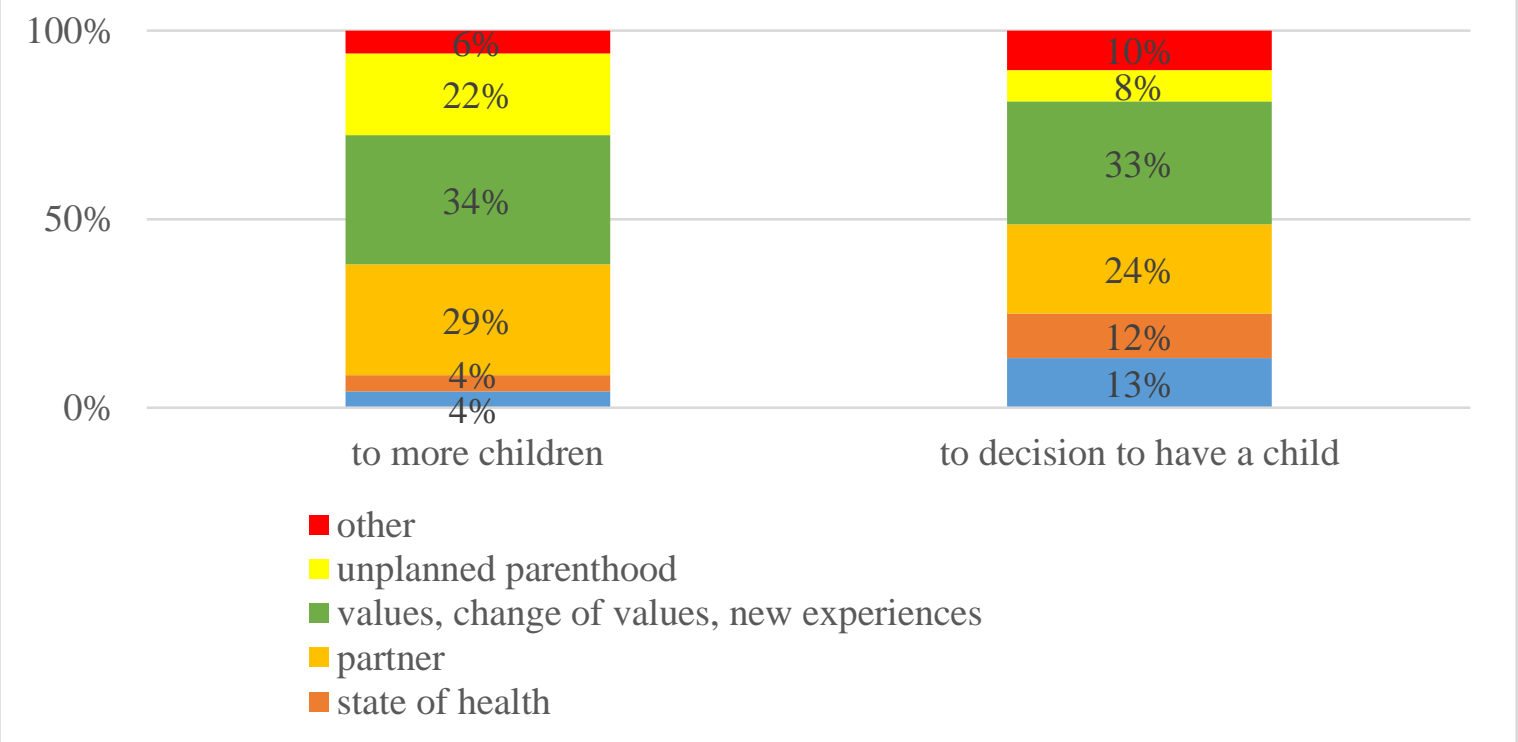

Note: Change to more children $(N=228)$; change to decision to have a child $(N=161)$.

Source: Life Course 2010 survey.

Fewer people make upward changes in their lifetime fertility intentions during adulthood but if they do, then values, a change in values and new experiences represent the most commonly cited reason (34\%), partner ranks second (29\%) and unplanned parenthood is third $(22 \%)$. When the change leads to the decision to have a child, again it is values, a change in values and new experiences that figure in first place (33\%), partner is the second most common reason cited (24\%), followed by economic situation (13\%), state of health $(12 \%)$ and unplanned parenthood (8\%).

\section{Discussions}

Our study explores what individual characteristics contribute in Czechia to the nonfulfilment of short-term fertility intentions and to changes in lifetime fertility intentions in the sense of a change in the total number of children a person plans to have. We tie in with previous studies that have mapped people's fertility intentions and analysed factors that contribute to the non-fulfilment of those intention. We also tie in with studies that have examined how fertility intentions change over the course of life. This study expands on research to date by testing what factors play a role in both the non-fulfilment of short-term intentions and to changes in lifetime fertility intentions in the sense of the number of children a person plans to have in life.

In line with previous studies we found that fertility intentions are predictors of subsequent fertility but many short-term fertility intentions remain unfulfilled even in times of 
social and economic stability. We also observed that fertility intentions are negotiated in response to a person's experiences and conditions.

The two models in this study show the following: among those who intended to have a/nother child, the higher chance of not having a child within three years was observed among those respondents who did not intend or were uncertain about having a child within such a short time, as well as among men, people in their teens or early twenties, people without a partner, and those who had already reached the widely shared ideal family size of two children. The people who have a higher chance of changing their lifetime fertility intentions, i.e. how many children they intend to have over the course of life include women, people with non-normative parental intentions (they want fewer or more than two children), people with a more extensive partnership history, those who have experienced unemployment, those who have at least one sibling, and people from the cohorts in Czechia who started to postpone childbearing.

Let's examine the results of two models above and discuss the various factors that were found to be relevant to the non-fulfilment of fertility intentions and to changes in lifetime fertility intentions in more detail here. As expected from previous literature (e.g. Iacovou and Tavares, 2011; Št’astná, 2011; Szalma and Takács, 2015), the lack of a partner proved to be an important factor contributing to not having a (another) planned child within the short-term period. In contrast, the more partners the respondents had, the more likely it was that their lifetime fertility intentions, i.e. the total number of children they wanted, changed in adulthood. This seemingly contradictory finding is in line with another stream of literature. Given that partners' fertility intentions may differ, both partners may adjust their childbearing expectations in a process of negotiation. Therefore, the explanatory power of models of childbearing intentions increase when the spouse's intentions are included (Thomson, 1997). As Iacovou and Tavares (2001) noted, mainstream literature on fertility intentions have focused mainly on the downward effect of the disagreement between partners on their fertility intentions. This study suggests, however, that for more than a quarter of those who changed their fertility intentions upwards, they believed that the influence of their partner was crucial. Moreover, the impact of their partner on the upward change in the number of children they intended to have was the second most often cited reason for the change. The finding that a more extensive partnership history increases the chance that a person's fertility intentions will change may reflect the fact that people adjust their fertility intentions to their partners' intentions and life trajectories. However, it may only reflect the effect of partnership dissolution and re-partnering. In sum, partnership has an important effect on fertility intentions: having a partner increases the chance of having a child as soon as intended; a more extensive partnership history means a greater chance of a person's lifetime fertility intentions changing; and partners' disagreement over their fertility intentions may lead to both downward and upward changes in fertility intentions.

Among the people who intended to have a child, women proved to be more likely to have the child as soon as they intended. But they were also found to change their intended total number of children more often than men. This may be associated with biological and age norms related fertility revisions, which seem to be more pronounced in the case of women than men (e.g. Hašková, 2009, p. 264).

Our models did not confirm any significant relationship between education on the one hand and the fulfilment of short-term fertility intentions or changes in the intended overall number of children on the other hand. Greater labour market instability/insecurity (measured as the experience of unemployment) proved, however, to be connected to changes in the intended total number of children. Similarly to Št'astná (2011), we did not find a statistically significant effect of the employment status on the chance of fullfiling short-term fertility intentions in the period of economic stability and growth though.

Our results are consistent with the findings of some studies while others have shown different results. The different results of various studies on the effect of education and labour 
market instability are likely to stem from region-specific differences, differences in the sense of measuring the effect in the time of economic decline or growth, and differences in the way labour-market instability and changes in fertility intentions are operationalised in research.

The effect of siblings on the chance of a person's fertility intentions changing is not commonly tested but some studies suggest that siblings' reproductive behaviour may influence one's fertility intentions (e.g. Szalma and Takács, 2018; Hašková, 2009). The higher chance of (lifetime) fertility intentions changing in adulthood that our study identified among people with at least one sibling can be understood in the light of existing research on fertility, peers, and social networks. While it is established knowledge that people adapt their fertility intentions to their partner's intentions and life trajectories, they are also influenced by their peers (Bernardi, 2002). Our research suggests that siblings are just a special kind of peer group with whom a person may compare or synchronise their life trajectories. Moreover, it has been noted by other research that grandparents' capacity and willingness to support an adult child (e.g. in the sense of providing childcare) have an effect on their adult children's fertility intentions and outcomes (Železná, 2018, p. 181). This could be more pronounced in such welfare contexts as that in Czechia, where the availability of non-family childcare is scarce (Hašková and Dudová, 2016). And how willing and able grandparents are to provide this kind of support can be greater or lesser depending on how much support they also have to provide the adult child's siblings in the form of caring for their children. This could be another way in which the life trajectories of siblings may influence a person's fertility intentions.

Regarding the effect of age and cohort, the fact that very young people (under the average age of women at first birth) were less likely than people in prime reproductive age to have a child within the studied three-year period is consistent with the findings of previous studies (Št'astná, 2011; Testa and Toulemon, 2006). The reason is that young people still have a relatively long period of time ahead of them in which to have children, which allows them to postpone their childbearing plans. The influence of age norms and peers can also be considered: given that these people are younger than the average age, expected age, and, what according to public opinion research is viewed as the ideal age at which to become a mother or father (Čadová, 2016), for them parenthood would still be inconsistent with the 'expected timetable of life' (Liefbroer and Billari, 2010) and would make them differ significantly from their peer group. Both age norms (or rather the 'expected timetable of life', in this late modern time) and peer-group pressure thus today probably work against having children between the ages of 20 and 25 (see Hofäcker and Chaloupková, 2014 for the notion of re-standardisation or "new standard"), which is the age at which the majority of men and women became parents in the "old reproductive regime' during the state-socialist period.

It is not just a person's age that matters for fertility intentions but also the year in which a person was born. The year of birth determines the age at which a person experiences important moments and changes in society, which could have an influence on their fertility intentions, depending on what age they were (and in what stage of the reproductive trajectory they were) when these social changes occurred. The finding that in Czechia it was people born in the second half of the 1960s and the first half of the 1970s who were more likely during adulthood to have changed the number of children they intended to have is a sign of the effect the social transformation after 1989 had on fertility intentions. People born in the second half of the 1960s and the first half of the 1970s were impacted by the changes in Czech society after 1989 at an age when people tend to engage most in making fertility plans and fulfilling those intentions. And in this region they were the ones who ushered in the 'new reproductive regime'. Older people for the most part had had children when they were very young, just over the age of 20 , while still living in the state-socialist regime. And younger people reached prime reproductive age at a time when the average, expected, and, according to public opinion, the ideal age to become a parent had already increased and at a time when the conditions in society were also 
less turbulent. Since the youngest group of respondents were still relatively young when surveyed, it is also possible that a significant share of them will change their intended number of children later in life. In this case another interpretation could be more appropriate. The results would indicate that there is a positive link between the increasing length of time people spend in the stage of 'young adulthood', during which time young people remain free from any parental obligations, and more unstable lifetime fertility intentions. It will only be possible to test whether the first or the second interpretation of the findings is more likely on the basis of more recent data. Regardless, however, the outcome of this study adds to the rich body of literature examining the influence the social transformation after 1989 had on fertility intentions and the fulfilment of fertility intentions or change in them in central and Eastern Europe.

Last but not least our study underlined an important relationship between childbearing norms on the one hand and the fulfilment of fertility intentions or changes in them on the other hand. Many authors have noted the prevalence of a two-child norm across European countries (Berrington, 2004; Sobotka and Beaujouan, 2014). Morgan and Rackin (2010) stated that the normative ideal of the two-child family results from two forces: there is an upward pressure on the number of children to have that relates to concerns about raising a single child, but the perception that three children constitutes a large family acts as a downward pressure. Following from studies demonstrating the existence of the two-child norm, our study adds that in Czechia this norm may affect fertility intentions and the fulfilment or revision of those intentions. Not only do our data show, like previous studies, that a large share of people in Czechia still want and plan to have a two-child family. People who already have two children are less likely to fulfil their plan to have another child than those who have not yet met the two-child norm. Our study also revealed that people whose fertility intentions fit the two-child norm have more stable fertility intentions than do people whose fertility intentions are to have more or fewer than two children and who formulated those intentions usually once they were already adults based on experiences and events in their life.

In sum, the two logistic regression models were helpful in testing what factors contribute to the unfulfilment of short-term fertility intentions and what factors contribute to changes in the number of children a person intends to have. Descriptive statistics on the factors respondents gave as the main reasons explaining the downward or upward changes in their intended number of children were also informative.

In line with the previous literature our results confirm that the main reasons people give for changing their fertility intentions towards uncertainty about whether to have a child at all and towards the decision to remain childless is their partnership situation (and especially the absence of a partner). The fact that since the 1990s in Czechia there has been a significant increase among young people in the length of time they spend in life without a permanent partner and often still live with their parents (Chaloupková, 2010, p. 167) indicates that the absence of a partner during a person's reproductive period of life will continue to be a significant factor that will lead some people to change the number of children they expected to have to zero. The fact that economic factors were cited as the main reason for changing their fertility intentions by almost $30 \%$ of those who said they adjusted their fertility intentions downward to a smaller number of children and by almost one-quarter of those who said they changed their fertility intentions towards being uncertain about whether they would even have a child at all, but only by one in six of the people who said they changed their fertility intentions to the decision to remain childless also indicates that although economic circumstances are not usually the main reason why people end up childless, economic factors do play an important role in people's decision to decrease the number of children they plan to have. It is also worth noting that health conditions were mentioned as the main reason for downward changes in fertility intentions by about a fifth to a quarter of respondents who declared such a change. If fertility below the replacement level (2.1 children per woman) and the mismatch between planned, and achieved fertility are 
considered to be a political issue, these findings may serve as one of the bases on which to formulate policy recommendations.

This study also shows that people make changes in the timing of childbirth to a time earlier than they intended and make upward changes in their fertility intentions, i.e. increase the intended total number of children, far less often than they make downward changes. But if they do increase the number of children they intend to have, then a change in values/new experiences and the influence of their partner are the main reasons they believe explain the change in their fertility plans. People's attitudes may change over the life course in response to new information people receive from their observations of others, their own experiences, changing circumstances, and insights into their own personalities. The results of our analysis suggest that if value changes and new experiences in the course of adulthood are mentioned as the main reason for a change in the intended number of children, it is more an upward than a downward change that they produce. This 'internal circumstance' contrasts with the somewhat external circumstances (namely, the absence of a partner, health, and economic constraints) that are mainly behind downward changes. The minor importance of unplanned parenthood for the decision to become a parent may reflect the huge increase in the use of modern contraceptives when planning whether and when to become a parent, yet it continues to be an important factor for explaining an increase in the expected total number of children.

Although quantitative research is strong in testing what factors are associated with un/fulfilling and changes in fertility intentions, qualitative research would be useful to complement the findings mentioned above. Qualitative research can help to understand the meanings of un/fulfilling short-term fertility intentions and the meanings of changes in lifelong fertility intentions, given by the people themselves. Moreover, process-oriented qualitative research can be illuminating when trying to understand the social mechanisms leading to unfulfilment and changes in fertility intentions (e.g. Hašková, 2009). Such process-oriented qualitative research on unfulfilment and changes in fertility intentions could complement, deepen and triangulate the above mentioned findings driven from quantitative data that were used to test whether the selected factors contribute to the studied processes of unfulfilling and changes to fertility intentions or not, but cannot reveal the mechanisms involved in these processes nor the meanings of the studied processes. More concretely, future qualitative research could help to understand the different meanings of processes leading to unfulfilling and changes in fertility intentions. Moreover, the mechanisms of the influence of siblings, extensive partnership history, health and fertility-related norms (among others) on changes in fertility intentions could be better explored by qualitative research that would build on the present research outcomes. Last but not least, the higher turbulence in fertility intentions among the cohorts of people who started the 'new reproductive regime' in the country that was shown in the quantitative data could be better understood through complementing the statistical data with biographical narratives of those who brought the 'new reproductive regime' compared to those older and younger to them.

\section{Conclusions}

Studies devoted to fertility intentions usually focus on short-term fertility intentions and in some cases also whether or not these plans are fulfilled, or they study lifetime fertility intentions in the sense of the total number of children they plan to have (and sometimes also changes in the lifetime fertility intentions over the course of life). This study contributes to knowledge in this area by testing what individual characteristics contribute to both the nonfulfilment of short-term fertility intentions and changes in lifetime fertility intentions. The data reveal that a number of individual characteristics are associated with both of these processes which together contribute to the postponement of childbearing and the mismatch between intended and achieved fertility in Czechia. 
Given that we analysed fertility intentions in the specific post-socialist context and with a view to the cohort effect, our study also contributes to the understanding of Czech society's rapid transition to the 'new reproductive regime'. The postponement of childbearing and lower completed cohort fertility (than in cohorts that achieved their fertility intentions before 1989) are typical features of the 'new reproductive regime'.

Moreover, our study suggests that an absence of a partner contributes to the nonfulfilment of short-term fertility intentions and health and economic difficulties and absence of a partner contribute to downward changes in lifetime fertility intentions. Families with small children rank among the groups of people who are more often at risk of income poverty in Czechia, and Czechia belongs to the countries in eastern and southern Europe where young people live in the parental home longer than they do in countries in northern and Western Europe (e.g. Iacovou, 2011; Eurostat, 2017). Consequently, the policy lesson from this study would be that it is necessary to invest in measures designed to improve the conditions (e.g. housing, employment) for young people to start their own household and to improve the economic and work-life balance situation in families. In European comparison, Czechia is a country with low availability of childcare services, high employment gap between women with and without children (OECD Family Database, 2018), low availability of part-time work (Kuchařová et al., 2017, p. 245) and high unemployment rate among women immediately after their childcare related leave (Bičáková and Kalíšková, 2015, p. 22). The lack of childcare services, long and inflexible working hours and weak enforcement of work-life balance policies contribute to difficulties of mothers to return to the labor market, families to come out with money and to problems of couples to have as many children as they wish (Kuchařová et al., 2017). Therefore, childcare-, leave-, and work-life balance policies to combat these shortcomings and problems seem to be inevitable to reduce the mismatch between intended and achieved fertility in Czechia. Moreover, a relatively large share of respondents referring to health issues as a reason for a downward change in their fertility intentions signalizes, in line with a study by Št'astná et al. (2017), that health-related problems seem to be an important factor in the processes of delaying childbearing and changes in fertility intentions. To understand the mechanisms of how the factors, which were revealed and tested in this study, intervene the processes of unfulfilling and changes in fertility intentions, and to examine people's understanding (meanings) of these processes, process-oriented qualitative research would be useful to complement the presented variable-oriented quantitative analysis. Such qualitative research may also help to specify the diversity of targeted policies needed to help populations at various intersections of social categories (including marginalized populations that are difficult or impossible to examine in country level representative surveys) to having as many children as they wish.

\section{Acknowledgments}

The research was funded by Czech Science Foundation (grant number 17-04465S) and by institutional support RVO: 68378025.

We thank to editor and to two reviewers for their useful comments to improve this article.

\section{Bibliography}

1. Beaujouan, É. and Solaz, A., 2013. Racing against the biological clock? Childbearing and sterility among men and women in second unions in France. European Journal of Population, 29(1), pp. 39-67.

2. Bernardi, L., 2003. Channels of social influence on reproduction. Population research and population review, 22(5-6), pp. 427-555.

3. Berrington, A., 2004. Perpetual Postponers? Women's, Men's and Couple's Fertility Intentions and Subsequent Fertility Behaviour. Population Trends, 117, pp. 9-19. 
4. Bičáková, A. and Kalíšková, K., 2015. Od mateřstvi k nezaměstnanosti: Postavení žen s malými dětmi na trhu práce. Praha: IDEA CERGE-EI.

5. Buhr, P. and Kuhnt, A.K., 2012. Die kurzfristige Stabilität des Kinderwunsches von Kinderlosen in Ost-und Westdeutschland: eine Analyse mit den ersten beiden Wellen des deutschen Beziehungs-und Familienpanels. Zeitschrift für Familienforschung, 2012, pp. 275-297.

6. Čadová, N., 2016. Postoje českých občanů k manželství a rodině - únor 2016. Tisková zpráva zvýzkumu Naše společnost, [online] Available from: <ttps://cvvm.soc.cas.cz/cz/tiskove-zpravy/ostatni/vztahy-a-zivotni-postoje/2018-postojeceskych-obcanu-k-manzelstvi-a-rodine-unor-2016> [Accessed 2 August 2018].

7. Chaloupková, J., 2010. Proměny rodinných a profesních startů. Prague: Institute of Sociology, Czech Academy of Sciences.

8. Fahlén, S. and Oláh, L., 2018. Economic uncertainty and first-birth intension in Europe. Demographic Research, 39 (28), pp. 795-834.

9. Hašková, H., 2009. Fenomén bezdětnosti. Prague: SLON.

10. Hašková, H. and Dudová, R., 2017. Institutions and Discourses on Childcare for Children Under the Age of Three in a Comparative French-Czech Perspective. Sociological Research Online, 22(3), pp. 120-142.

11. Hayford, S., 2009. The evolution of fertility expectations over the life course. Demography, 46(4), pp. 765-783.

12. Hofäcker, D. and Chaloupková, J., 2014. Patterns of Family Life Courses in Europe between Standardisation and Diversity. A Cross-national Comparison of Family Trajectories and Life Course Norms in European Countries. Comparative Population Studies, 39(3), pp. 559-586.

13. Iacovou, M., 2011. Leaving Home: Independence, Togetherness and Income in Europe. Expert paper No. 2011/10. UN, Department of Economic and Social Affairs, Population Division.

14. Iacovou, M. and Tavares, L.P., 2011. Yearning, Learning, and Conceding: Reasons Men and Women Change Their Childbearing Intentions. Population and Development Review, 37(1), pp. 89-123.

15. Kuchařová, V., Vidovičová, L., Barvíková, J., Hohne, S., Janurová, K., Nešporová, O. and Paloncyová, J., 2017. Zpráva o rodině. Prague: VÚPSV.

16. Kuhnt, A.K., Kreyenfeld, M. and Trappe, H., 2017. Fertility Ideals of Women and Men Across the Life Course. In: M. Kreyenfeld and D. Konietzka (Eds.). Childlessness in Europe: Contexts, Causes, and Consequences. Cham: Springer. pp. 235-252.

17. Liefbroer, A.C. and Billari, F.C., 2010. Bringing Norms Back In: A Theoretical and Empirical Discussion of Their Importance for Understanding Demographic Behaviour. Population, space and place, 16, pp. 287-305.

18. Miettinen, A. and Szalma, I. 2015. Childlessness Intentions and Ideals in Europe. Finnish Yearbook of Population Research 2014, 49, pp. 31-55.

19. Morgan, S.P. and Rackin, H., 2010. The Correspondence Between Fertility Intentions and Behavior in the United States. Population and development review, 36(1), pp. 91-118.

20. Murinkó, L. and Szalma, I., 2016. Men's Fertility in Second Unions in Three European Countries: The Effect of Parenthood Status. Finnish Yearbook of Population Research, 50, pp. $53-70$.

21. Ní Bhrolcháin, M., Beaujouan, É. and Berrington, A., 2010. Stability and change in fertility intentions in Britain, 1991-2007. Population Trends, 141, pp. 10-32. 21.

22. Philipov, D., Spéder, Z. and Billari, F., 2005. Now or Later? Fertility Intentions in Bulgaria and Hungary and the Impact of Anomie and Social Capital. Vienna: Vienna Institute of Demography. 
23. Rabušic, L. and Chromková Manea B.E., 2013. Velikost rodiny - postoje, normy a realita. Demografie, 55(3), pp. 208-219.

24. Riskind, R.G. and Patterson, C.J., 2010. Parenting Intentions and Desires Among Childless Lesbian, Gay, and Heterosexual Individuals. Journal of Family Psychology, 24(1), pp. 7881.

25. Smallwood, S. and Jefferies, J., 2003. Family Building Intentions in England and Wales: Trends, Outcomes and Interpretations. Populations Trends, 112, pp. 15-28.

26. Sobotka, T., 2004. Postponement of Childbearing and Low Fertility in Europe. Amsterdam: Dutch University Press.

27. Sobotka, T., Skirbekk, V. and Philipov, D., 2011. Economic recession and fertility in the developed world. Population and development review, 37(2), pp. 267-306.

28. Sobotka, T. and Beaujouan, É., 2014. Two is best? The persistence of a two-child family ideal in Europe. Population and Development Review, 40(3), pp. 391-419.

29. Spéder, Z. and Kapitány, B., 2009. How are Time-Dependent Childbearing Intentions Realized? Realization, Postponement, Abandonment, Bringing forward. European Journal of Population, 25, pp. 503-523.

30. Šprocha, B., Šídlo, L., Nováková, G. and Št’astná, A., 2016. Kohortní změny v koncentraci plodnosti v Česku a na Slovensku. Sociológia, 48(5), pp. 474-499.

31. Šprocha, B., Tišliar, P. and Š́dlo, L., 2018. A cohort perspective on the fertility postponement transition and low fertility in Central Europe. Moravian geographical reports, 26(2), pp. 109-120.

32. Št'astná, A., 2011. Realisation of Childbearing Intentions in the Czech Republic. Demografie, 53(4), pp. 321-332.

33. Št’astná, A., Slabá, J. and Kocourková, J., 2017. Plánování, načasování a důvody odkladu narození prvního dítěte v České republice. Demografie, 59, pp. 207-223.

34. Szalma, I. and Takács, J., 2015. Who Remains Childless? Unrealized Fertility Plans in Hungary. Czech Sociological Review, 51(6), pp. 1047-1075.

35. Szalma, I. and Takács, J., 2018. Is There Voluntary Childlessness at All in Hungary? In: N. Sappleton (Ed.). Voluntary and Involuntary: The Joys of Otherhood? Emerald Publishing Limited. pp. 309-337.33.

36. Testa, M.R. and Toulemon, L., 2006. Family Formation in Frnace: Individual Preferences and Subsequent Outcomes. In: In Vienna Yearbook of Population research 2006. Vienna: Austrian Academy of Sciences. pp. 41-75.

37. Thomson, E., 1997. Couple childbearing desires, intentions, and births. Demography, 34(3), pp. 343-354.

38. Železná, L., 2018. Intergenerational solidarity and the influence of informal transfers on fertility behaviour. Brno: Masaryk University.

39. ***Eurostat, 2017. When are they ready to leave the nest?, [online] Available from: $<$ https://ec.europa.eu/eurostat/en/web/products-eurostat-news/-/EDN-201705031>[Accessed 15 December 2018].

40. ***OECD Family Database, 2018. [online] Available from: <http://www.oecd.org/els/family/database.htm>[Accessed 23 February 2018]. 